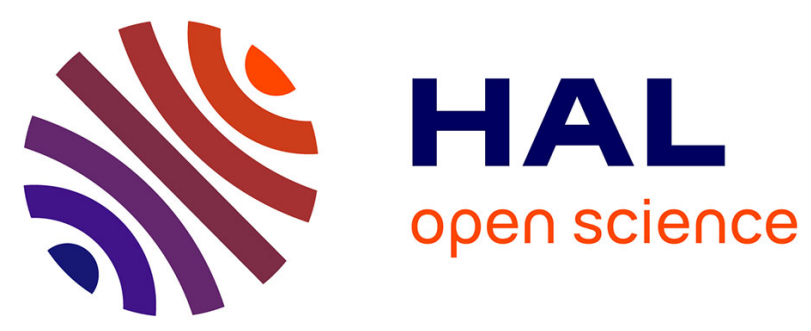

\title{
From Glass to Glaze in al-Andalus: Local Invention and Technological Transfer
}

\author{
Elena Salinas, Jorge de Juan, Juan M Piñero, M. Teresa Casal, Nadine \\ Schibille, Trinitat Pradell
}

\section{- To cite this version:}

Elena Salinas, Jorge de Juan, Juan M Piñero, M. Teresa Casal, Nadine Schibille, et al.. From Glass to Glaze in al-Andalus: Local Invention and Technological Transfer. European Journal of Archaeology, 2021, 10.1017/eaa.2021.23 . hal-03328197

\section{HAL Id: hal-03328197 https://hal.science/hal-03328197}

Submitted on 29 Aug 2021

HAL is a multi-disciplinary open access archive for the deposit and dissemination of scientific research documents, whether they are published or not. The documents may come from teaching and research institutions in France or abroad, or from public or private research centers.
L'archive ouverte pluridisciplinaire HAL, est destinée au dépôt et à la diffusion de documents scientifiques de niveau recherche, publiés ou non, émanant des établissements d'enseignement et de recherche français ou étrangers, des laboratoires publics ou privés. 
European Journal of Archaeology

Manuscript received 30 September 2020, revised 19 January 2021, accepted 21 May 2021

Running head (recto): E. Salinas et al. - From Glass to Glaze in al-Andalus

\title{
From Glass to Glaze in al-Andalus: Local Invention and Technological Transfer
} Elena Salinas ${ }^{1,5}$, Jorge De Juan ${ }^{2,6}$, Juan M.Piñero ${ }^{3}$, M. Teresa Casal ${ }^{4}$, Nadine SChibille $^{2}$ ANd Trinitat Pradell ${ }^{1}$

\author{
${ }^{1}$ Department de Física, Universitat Politècnica de Catalunya, Barcelona, Spain \\ ${ }^{2}$ Institut de recherche sur les archéomatériaux, CNRS/Université d'Orléans, France \\ ${ }^{3}$ Departamento de Prehistoria y Arqueología, Universidad de Granada, Spain \\ ${ }^{4}$ Departamento de Historia del Arte, Arqueología y Música, Universidad de Córdoba, \\ Spain \\ ${ }^{5}$ CEI·MAR / Departamento de Geografía, Historia y Humanidades, Universidad de \\ Almería, Spain \\ ${ }^{6}$ School of Arts and Humanities, University of Lisbon, Portugal
}

It has long been assumed that lead glazing technology preceded glassmaking in the Western world and that the technological transfer was from glazes to glass. Here, we present new evidence for the reverse, the indigenous innovation of glassmaking and its transfer to glazes in early Islamic al-Andalus (Spain). Compositional analyses show that Islamic lead glazes from Córdoba are intimately related to a distinct type of high-lead glass, suggesting a connection between the two technologies. The archaeological remains from a pottery workshop indicate that the glazing process initially involved the production of a lead glass and is not linked to earlier Roman or other contemporary glazing technologies. The data also demonstrate that the potters not only used the same materials and techniques but borrowed stylistic and decorative models from glassmaking. Keywords: glaze technology, lead glazed ceramic, early medieval technology, pottery workshop, glass crucible

\section{INTRODUCTION}

Archaeological and archaeometric data indicate that up to the early ninth century CE there was no local primary production of glass in the Iberian Peninsula. Only secondary glass 
working and the recycling of glass are well documented. During the fifth to eighth centuries CE, glazed ceramics are entirely absent from the archaeological record in Iberia, suggesting that there was no manufacture of glass or glazes before the Arab conquest. We recently identified clear evidence for the earliest local primary production of glass among the glass finds in Córdoba, dating to between the second half of the eighth century to the first quarter of the ninth century CE. This glass has a peculiarly high lead composition not encountered anywhere else. During the 870 s, lead-glazed ceramics appear in al-Andalus too. Intriguingly, these early lead-glazed wares are compositionally related to the glass of Shaqunda (Salinas \& Pradell, 2018; Schibille et al., 2020). These recent results have raised doubts about the theory which contends that glazing technology was introduced through a connection with other Islamic territories; rather, they suggest an autochthonous innovation and a transfer to glazes within al-Andalus.

\section{Archaeological and historical evidence}

As elsewhere in the Mediterranean, the glass supply in the Iberian Peninsula during antiquity and the early Middle Ages relied exclusively on the import of glass from the primary production centres on the Levantine coast and Egypt (De Juan \& Schibille, 2017). At the beginning of the eighth century, natron glass from the eastern Mediterranean no longer arrived in large quantities in Iberia, leading to increased recycling practices, reflected in an accidental contamination by colouring and opacifying agents (Freestone 2015; De Juan et al., 2019). Recycling of glass cullet was common practice since Roman times but increased dramatically in the seventh and eighth centuries in the Iberian Peninsula, as well as in Italy (Mirti et al., 2000; Mirti et al., 2001). The first evidence of an Iberian primary production of raw glass with a chemical composition different from Roman and Late Antique glass groups comes from the Rabad of Shaqunda (Schibille et al., 2020), the largest Islamic suburb of Córdoba of the early Emirate (c. 750-818 CE) (Figure 1) (Casal, 2018). The most striking characteristic of approximately a quarter of the glass finds is that they contain lead and silica as their main constituents, which clearly distinguishes them from earlier soda-lime-silica glass as well as from Islamic plant-ash glass from the eastern Mediterranean (e.g. Henderson et al., 2016; Phelps et al., 2016). Several structures, furnaces, lead fragments and a vessel interpreted as a crucible which supposedly belong to a glass workshop (Piñero et al., 2009) (see Figure 1) have been found at the Rabad of Shaqunda at Córdoba although they have not yet been analysed. 
Arabic written sources also allude to a local Córdoban invention of glass roughly around the time the site of Shaqunda was occupied. Ibn Hayyān, for instance, describes the invention of a method 'to produce glass from mineral/stones' (الحجارة) by Abbās Ibn Firnās (810?-887 CE; Ibn Ḥayyān, 2001: 137). The same author attributes the introduction of the use of fine glass tableware instead of gold and silver at the court of the emir 'Abd al-Raḥmān II (822-852 CE) to the famous singer Ziryāb from Bagdad (Ibn Hayyān, 2001: 206).

Lead glazes were first produced in Anatolia during the first century BCE. From there, the technology was adopted in the Roman and Byzantine regions (De Benedetto et al., 2004; Waksman et al., 2008) and continued into the medieval Islamic culture of the eighth century in Syria and Egypt (Tite, 2008; Watson, 2014) and later in ninth-century Iraq (Wood et al., 2009), where the previous Sassanid tradition involved alkali glaze technology (Mason \& Tite, 1997; Paynter, 2001).

The production of lead glazes involved the application of a suspension of either a lead oxide by itself or a mixture of a lead oxide and silica in the Roman period (De Benedetto et al., 2004) and Byzantine era (Waksman et al., 2008). Contrary to alkali-lime glazes, lead glazes did not require previous fritting. In fact, the simplicity of the preparation and application was a main advantage of lead over alkali-lime glazes (Tite et al., 1998).

Although lead glazes continued to be produced in some European regions during the early medieval period, in particular in Italy (the so-called vetrina pesante), glazed ceramics disappeared completely in Iberia during the Visigothic period (476-11 CE) (e.g. Caballero et al., 2003). The alleged existence of a pre-Islamic production of 'thick glazed ceramics' in the seventh and eighth centuries (Alba \& Gutiérrez, 2008) has been refuted since have been recognized the ceramics as crucibles for secondary glass production). At Pechina (Figure 1), the production of lead-glazed ware has long been regarded as the earliest evidence in al-Andalus after the disappearance of the Roman glazing tradition. This early pottery workshop has been dated to the second half of the ninth century (Castillo \& Martínez, 1993). The analysis of the structures and debris found there has provided valuable information about the materials and procedures used in the production of lead glazes. According to the chaîne opératoire, the Pechina potters first produced a lead glass, which was then crushed and applied over the biscuit-fired ceramics and fired to produce a continuous glaze (Salinas et al., 2018). This procedure has no parallels in earlier Roman and Byzantine or contemporary Islamic technology. 
Pechina is not the only lead glaze workshop identified in al-Andalus in the Umayyad emirate. Evidence of local lead glaze production has also been found in Córdoba and Málaga, with characteristic ceramic and glaze compositions (Salinas \& Pradell, 2020. Furthermore, an early consumption of lead-glazed wares has been identified in some urban settlements. In particular, the lead glaze assemblage excavated in the eastern area of Córdoba at María Auxiliadora Street (Cánovas, 2006; see Figure 1 for location), with numerous parallels in other ninth-century archaeological sites in Córdoba (Fuertes \& Hidalgo, 2003; Salinas, 2013), has been analysed (Salinas \& Pradell, 2018). The chemical composition of the glazes shows a striking similarity to the lead glass from Shaqunda (Schibille et al., 2020).

The Córdoba glaze workshop was only recently located, when a collection of leadglazed ceramic wasters was found in the north-eastern part of the potters' quarter of the city (Zumbacón) (see Figure 1 for location). These discoveries have not yet been analysed; their study will prove particularly important as they may represent the missing link between lead glass and lead glaze production in the Iberian Peninsula.

\section{Glass and glaze}

The first local glass production in Córdoba (at Shaqunda) dates to $c .750-818 \mathrm{CE}$, while the earliest glaze workshop found in Córdoba (at Zumbacón) dates to the second half of the ninth century, indicating that the Shaqunda lead glass predates the first production of lead-glazed ware in Córdoba. Furthermore, their compositional similarities suggest a technological transfer from glassmaking to the manufacture of glazes in al-Andalus.

The origins of high lead glass are at present unclear. The first objects may be dated back to the Chinese Han dynasty (202 BCE-220 CE), when glass and glazed eye-beads of strikingly similar composition were produced, suggesting a link between the productions (Brill, 1999; Wood, 2001; Henderson et al., 2018). High lead glasses are quite rare further west (Brill, 1999; Krueger, 2014; Pollak, 2017). Examples in the eastern Islamic world typically date from the ninth to the twelfth centuries, thus somewhat later than the lead glass recovered from Córdoba (Oliver, 1961; Carboni \& Whitehouse, 2001). These eastern Islamic high lead glasses are overwhelmingly of a deep emerald green colour, and associated to deep-cut examples or with the emerald green upper layers of elaborately cut cameo vessels, the high lead content of the green emerald glass facilitating the cutting (Carboni \& Whitehouse, 2001). Lead glass has also been used for undecorated and mouldblown vessels (Shindo 2007; Krueger, 2014; Wypyski, 2015; Pollak, 2017). It is likely 
that the high lead family of glasses evolved from some closely related technology, such as ceramic glazing, glass or metal enamelling, or the manufacture of imitation gems (Carboni \& Whitehouse, 2001).

The objective of this study is therefore twofold: on the one hand, to ascertain the singularity and originality of the earliest Córdoba glass production and its connection with the production of glazed ware in Córdoba; and, on the other hand, to establish whether the technological transfer from glass to glaze can be verified. For this, glass fragments from domestic, manufacturing, and commercial contexts in Shaqunda and a crucible found in the glass workshop of Shaqunda are studied. Finally, a collection of glazed wasters from the Córdoba glaze workshop at Zumbacón together with the glazed wares from a Córdoba suburb (Maria Auxiliadora Street) are analysed and compared to the Córdoba glass.

\section{Archaeological Context}

\section{The Córdoba suburb and workshop of Shaqunda}

The suburb of Shaqunda is located on the south bank of the Guadalquivir river, opposite the Madina, the centre of political and religious power. Its construction began during the period of the independent Emirate of al-Andalus, established by the Umayyad emir 'Abd al-Raḥmān I in 756 CE. The conservation of a large sector containing archaeological structures and artefacts in this quarter has made it possible to propose an early urban model of the emirate period. The houses are arranged next to the various areas, both commercial (market) as well as productive/artisanal and for storage (Casal, 2018; Piñero et al., 2009). The study of the pottery, coins, and dietary habits of the population demonstrates an Islamized and Arabized society. Since it was razed to the ground by the emir al-Hakam I, Shaqunda was occupied over a short and precise time span (c. $750-818$ $\mathrm{CE})$.

A number of glass objects and domestic pottery were recovered from the core of the suburb (Casal et al., 2005). The glass finds consist partly of recycled material, some plant-ash glass imported from the Islamic east, and about one third of the assemblage is a high-lead glass. The lead glass group is composed of fifteen glass vessels, including small bottles or ointment containers, some beakers and bowls (Figure 2), and one glass bracelet (Schibille et al., 2020). The only decorations are glass threads applied to the surface of some fragments. Some edges are roughly worked, possibly related to the low viscosity and high density (weight) of lead glass that made it difficult to blow and work. 
All the pottery recovered from Shaqunda is unglazed and mostly related to domestic uses, such as cooking ware, tableware, lamps, as well as large storage jars. The pottery repertoire combines both pre-Islamic and Islamic traditions, while the decoration is very simple and limited to painted daubs, incisions, and impressions (Casal et al., 2005). No imported ceramics have been recovered.

In the western area of the suburb close to the cemetery, there was a structure identified as a glass workshop, which presumably belonged to a large artisanal area. The workshop comprises several rooms and three furnaces (Figure 3), two of which (2 and 3) were attributed to a first phase, while furnace no. 1 is associated with a second phase. The furnaces are structurally different: furnace no. 2 is circular, furnace no. 3, although badly preserved, was rectangular, and furnace no. 1 is semi-quadrangular with an annexed circular structure where the crucible was supposedly placed. The furnaces are made of bricks and pebbles and show evidence of having been exposed to fire. It was the presence of a crucible with a greenish vitreous layer and some irregular lead fragments that led the archaeologists to interpret this building as a glass workshop (Piñero et al., 2009), although no glass waste was found. This lack of glass waste can be explained by the fact that the workshop was not abandoned but moved to another place.

\section{The Córdoba Pottery Quarter}

The main quarter for pottery production in Córdoba during the Islamic period was located in the north-east of the city, outside the walls (Figure 1). Its long history spanned the ninth to the early thirteenth century. In the area known today as Zumbacón, more than 100 pottery kilns dated to the Emirate period (ninth to early tenth century) have been identified. Hence, the pottery workshop was active after Shaqunda was abandoned in 818 CE. The unglazed pottery recovered from the Zumbacón dumps are similar to those from Shaqunda but have a more diverse repertoire of shapes and decorations. This is due to the fact that Zumbacon glazed ceramics are slightly later (ninth century instead of eighth century), as confirmed by the stratigraphic sequences of other archaeological sites in Córdoba. The pottery wasters include the first evidence of glazed pottery production: glazed wasters, bars, and kiln stilts. The main glazed ceramic shapes recovered are closed forms such as beakers and pitchers, but also some open forms such as dishes (Figure 4). Monochrome glazes are combined with simple incisions and clay applications recalling glass vessels. With regard to the combination of glaze colours, two groups can be distinguished: vessels with a single colour glaze (green, honey-coloured, or brown) and 
those with two colours (one colour on each surface). Nineteen glazed ceramic vessels from this workshop have been analysed.

\section{The glazed ware from Maria Auxiliadora Street (Córdoba)}

A glazed ware assemblage was excavated in the eastern area of the city of Córdoba, at Maria Auxiliadora Street (Cánovas \& Salinas, 2009), identified by some historians as the Munyat al-Mugira suburb (Ocaña, 1963) (Figure 1). A collection of glazed and unglazed wares was recovered from the early medieval archaeological sequence dated to the late ninth to early tenth century. The assemblage shows numerous parallels with other archaeological sites in ninth-century Córdoba. Regarding the glazed pottery, five sherds are monochrome glazed pitchers, three of which have incised decorations; a further three beaker sherds are bichrome (honey and green) (see Figure 7A).

\section{RESULTS}

This section presents the results of the scientific and archaeological analyses. The analytical methods are included in the Supplementary Material.

\section{Glass from the Shaqunda suburb (Córdoba)}

The compositional structure of the glass assemblage from Shaqunda offers insights into the transition from the natron glass technology, which prevailed throughout antiquity, towards the new plant-ash glassmaking recipes that emerged in the Middle Ages (Schibille et al., 2020). The majority of the glass finds are natron-type with low magnesia and potash derived from the recycling of old material. Only a few fragments correspond to the contemporary natron glass groups from Islamic Egypt. A small fraction are plantash glasses of Mesopotamian origin with higher magnesium and potassium oxides, the earliest so far identified in al-Andalus.

The most relevant group for the present study is a group of high-lead glass that differs compositionally from Islamic lead silica glass from the eastern Mediterranean and Mesopotamia. It has on average 52 per cent lead and 34 per cent silica, with significant levels of alumina (4.7\%), lime (4\%), as well as some iron $(1.7 \%)$ and potash $(1.4 \%)$ (Supplementary Material: Table S1). It has elevated barium contents, but low silver and bismuth concentrations that suggest the use of lead slags generated during the smelting of lead ore. The analysis of the isotopic signature of five samples revealed that the plumbiferous material came from the mining districts north of Córdoba. Hence, it is the 
first known primary glass locally produced in the Iberian Peninsula (Schibille et al., 2020).

\section{The crucible from the Shaqunda workshop (Córdoba)}

The vitreous layer inside the ceramic crucible (Figure 5A-C) proved to be transparent high lead glass $\left(\begin{array}{llll}51 \% & \mathrm{PbO})\end{array}\right)$ with a very low content of sodium $\left(<1 \% \quad \mathrm{NaO}_{2}\right)$ (Supplementary Material: Table S1). The glass has a greenish colour due to the presence of $\mathrm{Fe}^{2+}$ resulting from the reducing conditions during firing. Wollastonite and diopside crystallites formed by the interaction of the ceramic with the glass have been identified and are shown in Figure $5 \mathrm{H}$, together with some carbon particles probably from ashes. The exterior (Figure 5D and 5E) has a darkened partially glazed surface probably resulting from having been directly placed in the fire.

The inner surface of the ceramic does not show any protective layer, and the glass adheres directly to the ceramic. The presence of some carbon particles suggests the possible presence of ash in the crucible, either from the fire applied below, or used to protect the inner surface. The results are therefore consistent with its use as a crucible for glass working. The composition of the vitreous layer matches that of the glass objects found in the area. These results confirm that transparent high-lead glass objects were blown and shaped in the workshop.

\section{Glazed ware from the pottery quarter (Córdoba)}

The chemical analyses of the transparent lead glazes are shown in Supplementary Material Table S1. The ceramics have one or two colours (one on each surface), green due to the addition of copper $(1.5-4.7 \% \mathrm{CuO})$ and honey-coloured from the addition of iron (1.7-6.9\% FeO). They are lead glazes with highly variable lead contents (33.6$58.2 \% \mathrm{PbO}$ ), possibly because they were all wasters that had been exposed to high temperatures or prolonged firings. As a consequence, part of the lead may have been lost through volatilization, while elements belonging to the ceramic fabrics may have diffused more extensively into the glaze.

Calcium contents range typically from 2.6 to 6.5 per cent $\mathrm{CaO}$, aluminium varies from 2.5 to 6.3 per cent $\mathrm{Al}_{2} \mathrm{O}_{3}$, and potassium contents are between 0.7 and 2.4 per cent $\mathrm{K}_{2} \mathrm{O}$, of which the higher amounts are associated with ceramic fragments that appear to a large degree overfired. With the exception of two extremely overfired samples (Z72 and Z45), sodium and magnesium contents are very low $(<1 \%)$. The two types of colour 
glazes are honey-coloured, which contains between 1.5 and 6.9 per cent $\mathrm{FeO}$ and very little copper mainly below the detection limits $(\sim 0.2 \% \mathrm{CuO})$, and green that contains between 1.5 and 4.7 per cent $\mathrm{CuO}$ and between 1.1 and 3.5 per cent $\mathrm{FeO}$.

The glazes are usually well preserved, showing occasional bubbles and undissolved quartz grains. Some glazes exhibit cracks perpendicular to the surface that formed by differential shrinkage of the glaze and ceramic body during cooling. The interfaces between the glaze and the fabric are developed and full of lead feldspars and iron pyroxene crystallites.

\section{Glazed ware from Maria Auxiliadora Street (Córdoba)}

The data in Table $\mathrm{S} 1$ show that all glazes contain between 43.5 and 53.5 per cent $\mathrm{PbO}$, between 1.1 and 5.6 per cent $\mathrm{CaO}, 3.4$ and 5.2 per cent $\mathrm{Al}_{2} \mathrm{O}_{3}$, and 1.2 and 2.1 per cent $\mathrm{K}_{2} \mathrm{O}$, while sodium and magnesium contents are very low $(<1 \%)$. The chemical composition of the glazes from the monochrome group is fairly homogeneous: the colours are green, obtained by the addition of copper with typical contents varying between 1.2 and 1.9 per cent $\mathrm{CuO}$, or honey-coloured, with higher iron contents between 2 and 3.6 per cent $\mathrm{FeO}$. Only one example is a bichrome transparent glaze (see Figure 7A) and has a honey-coloured inner surface, containing higher amounts of iron $(3 \% \mathrm{FeO})$, while the outer surface is green and contains copper (1.7\% CuO) (Salinas \& Pradell, 2018).

\section{DISCUSSION}

Comparing the compositional and stylistic features, we can confidently rule out any technological link between the earliest glazed wares from al-Andalus and those from other Islamic regions (Salinas \& Pradell, 2018). A North African connection with Ifriqiya (present-day Tunisia) was excluded due to a different technological tradition (i.e. alkali glazes) despite the geographical proximity of the two regions. No similarities in shape or decoration have been found between Andalusi and Abbasid high-lead glaze wares from, for example, Raqqa and Basra, or with Byzantine glazed ceramics. While the early Andalusi glazed repertoire is foot free and uses only one or two colours (green and honey/brown), contemporary glazed vessels from other Islamic lands are characterized by footed shapes, a wider range of colours (i.e. white, blue, yellow) and polychrome painted decorations. By contrast, close parallels between glazed ceramics and glass objects can be noted not only in al-Andalus (Salinas, 2013), such as the glass objects from Madīnat Ilbira (Malpica, 2013) and Madīnat al-Zahrā' dated to the ninth to tenth centuries 
(Rontomé, 2006), but also in the eastern Islamic world (i.e. Syria, Mesopotamia, Nishapur) (Carboni \& Whitehouse, 2001).

The chemical composition of the ceramic glazes, the Shaqunda glasses, and the glassy layer in the crucibles are very similar across the majority of base glass elements (Figure 6, Table S1). Minor differences in the alkali, alkaline earths, iron, and titanium levels can be ascribed to differing production procedures. High iron concentrations especially in the honey-coloured glazes, for instance, is caused by the deliberate addition of iron as a colouring agent, which probably also resulted in an increase in the titanium contents (Figure 6). The interaction between the ceramic body and the glaze during firing may account for the higher content of $\mathrm{CaO}, \mathrm{MgO}$, and $\mathrm{K}_{2} \mathrm{O}$, and lower $\mathrm{PbO}$, and generally broader compositional variability. Glass produced in large containers is less prone to contamination, and the subsequent firing in the crucibles to the softening temperature is made at a lower temperature and for a shorter amount of time than the glaze ware firing. Nevertheless, the lower $\mathrm{Na}_{2} \mathrm{O}$ contents of the glazes and the concomitantly enhanced $\mathrm{MgO}$ and $\mathrm{K}_{2} \mathrm{O}$ levels could also be the result of the use of ash to protect the crucible during the glass softening process, or these phenomena may simply be caused by fuel ash contamination.

The exact date for the start of glaze production in Córdoba is unknown, although comparison of the unglazed and glazed repertoire from the Zumbacón area with other glazed assemblages from Córdoba and al-Andalus confirms that it is later in date than the Shaqunda glasses. Not a single fragment of glazed pottery, either local or imported, was found in Shaqunda, the most important urban suburb of the capital of al-Andalus at that early time. On the other hand, the striking similarities in terms of colours, shapes, and some decorations with those from the Pechina workshop strongly suggest that the production of the Zumbacon workshop was contemporary with that at Pechina, in the second half of the ninth and early tenth centuries. Analyses of the workshop debris found in the industrial zone of the Córdoba glazed ware workshop agrees with the data provided by other contemporary Andalusi workshops such as Pechina (c. 875-900 CE), Málaga (c. 900-950 CE) and Murcia (c. 925-950 CE) (Molera et al., 2009; Salinas et al., 2018). These early Andalusi glaze workshops seem to have shared the same glazing method, in which a high-lead glass was first synthesized and then applied over a biscuit-fired ceramic vessel (Salinas et al., 2018), but they show different glaze compositions, a fact that allows us to recognize the production of each al-Andalus workshop. This glazing technology differed substantially from the Roman, contemporaneous European and Byzantine, or indeed other 
early Islamic techniques, where lead oxide or a mixture of lead oxide and sand was directly applied to the surface of the ceramic object before firing (Walton \& Tite, 2010).

Taken together, the data demonstrate that the production of lead glass was already well established by the time production of lead-glazed ceramics first emerged in alAndalus. Hence, contrary to what is commonly assumed for other Islamic regions (Brill, 2001, 2009), in Córdoba and more generally in al-Andalus, leadglass was produced first and later employed to produce glazed wares. Thus, al-Andalus presents a rare instance of a technological transfer from glass production to glazes and not vice versa, as appears to be the case in the eastern Islamic world.

The glass objects from the various archaeological sites in Córdoba dating to the late eighth to the early ninth centuries encompass bottles, beakers, and bowls. Due to the fragmentary nature of the finds, it is difficult to reconstruct their entire shape. The earliest glazed ceramics from Córdoba have been dated from the 870s-880s CE and are mainly pitchers, beakers, and bowls or dishes characterized by the absence of feet and showing a distinctive decoration (Salinas, 2013). The chronological gap between the assemblages precludes any direct typological comparison of glass objects and ceramic ware. However, glass objects from Córdoba and Madīnat al-Zahrā' belonging to the Caliphate (929-1031 CE) and Madīnat Ilbīra (ninth-tenth centuries) have similar shapes and decorations as Late Emirate glazed ceramics (c. 875-929 CE) (Figure 7A-C). Moreover, lead glass and glazes continued to be produced in the Caliphate period but with some differences in composition (Duckworth et al., 2014; Molera et al., 2018). The data therefore seem to indicate, on the one hand, a change in the shapes and decorative motifs both in glass and glazed ceramics over time and, on the other hand, a link between glass and glazed ware beyond the technology of production.

The decorative style of the earliest glazed ceramics from Córdoba is very characteristic, namely semi-circular incisions made with a half-ring or vertical and rhomboidal threads applied over a plain background, similar to the glass beaker found in Madīnat Ilbira and dated to the ninth-tenth century (Malpica, 2013: 143) (Figure 7B) as well as other eastern Islamic glass objects (Carboni \& Whitehouse, 2001). An explanation for these decorative features may be that the potters were copying glass and metallic models rather than contemporary Islamic glazed ceramics, reinforcing the idea of a technological connection between glass and glazes.

Why did this technological transfer occur in Córdoba in the ninth century? Several explanations can be advanced. First, in the absence of previous glazing traditions in the 
Iberian Peninsula, unlike in other regions where the glazing technology continued (Roman, Byzantine, and Coptic lead-glazed wares), the potters were forced to look for other solutions. Second, the remote geographical position of al-Andalus in relation to the core of the Abbasid caliphate meant that Abbasid potters were not encouraged to settle in Umayyad Córdoba or other Andalusi urban sites. Judging by the domestic ceramics from different early Andalusi settlements such as Shaqunda (Casal et al., 2005) and el Tolmo de Minateda (Amorós, 2018), new unglazed ceramic forms were incorporated into the local repertoire, related to novel culinary and domestic customs (portable baking ovens, drinking pitchers, oil lamps, globular bottles), in addition to agricultural practices (pots for waterwheels). These novelties were seen as proof of Islamization and Arabization (Gutiérrez, 2016). Nevertheless, neither eastern nor North African unglazed ceramic vessels have so far been identified in early Andalusi phases. Conversely, chemical analyses of some of the Shaqunda glass objects confirmed them to be Islamic imports (Schibille et al., 2020). This corroborates the arrival of exogenous luxury glass, but not ceramics during the eighth-early ninth century. Currently, the earliest evidence of glazed imports, identified as of Samarra type, has been reported at Ilbīra and dated to the second half of the ninth century (Carvajal, 2013).

Finally, the abundance of lead deposits in al-Andalus (Ibn Ḥayyān, 2001: 203-04) and waste products associated with the smelting of lead ores that form a glassy slag means that a ready-to-use relatively cheap material was available and could easily be transformed into glass and glazes. The temperature required for high-lead glass is lower than that needed to produce alkali silica glazes. It may not be a coincidence that the two earliest glazed ware production centres, Córdoba and Pechina, are located close to lead ore deposits that were exploited at the time. Access to the main raw material was an advantage that undoubtedly facilitated the development of this emerging technology.

In addition to these technical considerations, we should highlight a significant increase in the demand for material refinements and luxury goods related to the presence of the court and urban elites from 'Abd al-Raḥmān II (822-852 CE) and the new Abbasid fashions imposed by Ziryab. Even though the technical know-how for the production of glass and glaze did not reach al-Andalus in the eighth and ninth centuries, some new (so far not archaeologically documented) types and luxury objects should have arrived from the eastern Islamic world, at least from the second half of the ninth century if not before. This may have generated a local demand, leading to the invention of lead glass, which was used a few decades later to manufacture lead-glazed wares. The increase in demand 
for glass during the ninth century may have prompted the development of the production of transparent high-lead glazes in al-Andalus, since it was less fragile and probably cheaper than glass. There is no clear evidence of Emirate-period glass production outside Córdoba (even in Pechina), while, by contrast, the manufacture of glazed tableware spread quickly to other urban centres, like Málaga and Murcia, in the tenth century.

\section{Conclusions}

The historical, archaeological, and technological data presented here reflect the autochthonous innovation of a new glass technology and the subsequent technological transfer to glazing techniques in early Islamic al-Andalus in Spain. This development is diametrically opposed to what has been observed in other archaeological contexts where glazing technologies paved the way for glassmaking. The growth of both technologies in ninth-century al-Andalus was probably motivated by various factors, such as the lack of supplies of fresh raw glass from the eastern Mediterranean, the somewhat isolated geographical position of Umayyad al-Andalus in relation to both Latin Europe and the Islamic East, which appears to have prevented technological transmission but not the arrival of some novel artistic fashion trends emanating from the Abbasid court. The progress of local glassmaking and later lead glazing enabled the Umayyads of al-Andalus to take advantage of the abundant natural resources of their territory and at the same time promote their own industry of luxury products to develop and compete with eastern imports. It has previously been assumed that glaze technology came from the East. However, Andalusi potters employed a completely different technology. There is no evidence for the technological transfer of pottery glazing from the eastern Islamic lands or other Mediterranean regions to al-Andalus. Instead, the transfer came from local innovations in the glass industry.

\section{ACKNOWLEDGMENTS}

We would like to thank Isabel Larrea and the Gerencia de Urbanismo del Ayuntamiento de Córdoba for providing the samples analysed from the Córdoba potters' quarter. This project received funding from the European Union's Horizon 2020 research and innovation programme under the Marie Skłodowska-Curie scheme (grant agreement IGATO no. 702019 to ES), an ERC Consolidator Grant (grant agreement no. 647315 to Nadine Schibille), and from MINECO (Spain) (grant no. MAT2016-77753-R to Trinitat 
Pradell). The funding organization had no influence on the study design, data collection and analysis, decision to publish, or preparation of the manuscript.

\section{REFERENCES}

Alba Calzado, M. \& Gutiérrez Lloret, S. 2008. Las producciones de transición al Mundo Islámico: el problema de la cerámica paleoandalusí (siglos VIII y IX). In: D. Bernal \& A. Ribera, eds. Cerámicas hispanorromanas. Un estado de la cuestión. Cádiz: Universidad de Cádiz, pp. 585-613.

Amorós, V. 2018. El Tolmo de Minateda en la alta edad media. Cerámica y contexto. Alicante: Universidad de Alicante, Servicio de Publicaciones

Brill, R.H. 1999. Chemical Analyses of Early Glasses. Volumes 1 \& 2. Corning (NY): Corning Museum of Glass.

Brill, R.H. 2001. Some Thoughts on the Chemistry and Technology of Islamic Glass. In: S. Carboni \& D. Whitehouse, eds. Glass of the Sultans. New York: Metropolitan Museum of Art, pp. 25-45.

Brill, R.H. 2009. Chemical Analyses. In: J.W. Allan \& G.F. Bass, Serçe Limaní, Volume2. The Glass of an Eleventh-Century Shipwreck. College Station (TX): Texas A \& M University Press, pp. 459-96.

Caballero, L., Retuerce, M. \& Mateos, P., eds. 2003. Cerámicas tardorromanas y altomedievales en la Península Ibérica. Ruptura y continuidad. Madrid: Consejo Superior de Investigaciones Científicas.

Cánovas, A. \& Salinas, E. 2010. Actividad arqueológica preventiva en la calle maría Auxiliadora 17 y calle Jesús del Calvario (Córdoba). Anuario Arqueológico de Andalucía, 2005: 503-15.

Carboni, S. \& Whitehouse, D. eds. 2001. Glass of the Sultans. New York: Metropolitan Museum of Art.

Carvajal, J.C. 2013. Islamicization or Islamicizations? Expansion of Islam and Social Practice in the Vega of Granada (South-East Spain). World Archaeology, 45: 57-71.

Casal, M.T. 2018. The Rabad of Saqunda in Umayyad Córdoba (750-818 AD). In: L. Callegarin \& S. Panzram, eds. Entre civitas y madina: El Mundo de las ciudades en la Península Ibérica y en el Norte de África (siglos IV-IX). Madrid: Casa de Velázquez, pp. 119-32. 
Casal, M.T., Castro, E., López, R. \& Salinas, E. 2005. Aproximación al estudio de la cerámica emiral del arrabal de Šaqunda (Qurțuba, Córdoba). Arqueología y Territorio Medieval, 12: 189-236.

Castillo, F. \& Martínez, R. 1993. Producciones cerámicas en Bayyana. In: A. Malpica Cuello, ed. Primer encuentro de arqueología y patrimonio. La cerámica altomedieval en el sur de al-Andalus. Granada: Universidad de Granada, pp. 67-116.

De Benedetto, G.E., Acquafredda, P., Masieri, M., Quarta, G., Sabbatini, L., Zambonin, et al. 2004, Investigation of Roman Lead Glaze from Canosa: Results of Chemical Analysis, Archaeometry, 46: 615-24. $\quad$ https://doi.org/10.1111/j.14754754.2004.00177.x

De Juan Ares, J. \& Schibille, N. 2017. La Hispania antigua y medieval a través del vidrio: la aportación de la arqueometría, Boletín de la Sociedad Española de Cerámica y Vidrio, 56: 195-204. https://doi.org/10.1016/j.bsecv.2017.04.001

De Juan, J., Vigil-Escalera, A., Cáceres, Y. \& Schibille, N. 2019. Changes in the Supply of Eastern Mediterranean Glasses to Visigothic Spain. Journal of Archaeological Science, 107: 23-31. https://doi.org/10.1016/j.jas.2019.04.006

Duckworth, C., Córdoba, R., Faber, E., Govantes, D.J. \& Henderson, J. 2014. Electron Microprobe Analysis of 9th-12th century Islamic glass from Córdoba, Spain. Archaeometry, 57: 27-50. https://doi.org/10.1111/arcm.12079

Freestone, I.C. 2015. The Recycling and Reuse of Roman Glass: Analytical Approaches. Journal of Glass Studies, 57: 29-40.

Fuertes, M.C. \& Hidalgo, R. 2003. Cerámicas tardorromanas y altomedievales de Córdoba. In: L. Caballero, M. Retuerce \& P. Mateos, eds. Cerámicas tardorromanas y altomedievales en la Península Ibérica. Ruptura y continuidad. Madrid: Consejo Superior de Investigaciones Científicas, pp. 505-40.

Gutiérrez, S. 2016. La mirada del otro: al-Andalus. In: A. Molinari, R. Santangeli Valenzani \& L. Spera, eds. L'archeologia della produzione a Roma (secoli V-XV): atti del Convegno Internazionale di Studi, Roma, 27-29 marzo 2014). Roma: École française de Rome \& Bari: Edipuglia, pp. 583-96.

Henderson, J., Chenery, S., Faber, E. \& Kröger, J. 2016. The Use of Electron Probe Microanalysis and Laser Ablation-Inductively Coupled Plasma-Mass Spectrometry for the Investigation of 8th-14th Century Plant Ash Glasses from the Middle East. Microchemical Journal, 128: 134-52. https://doi.org/10.1016/j.microc.2016.03.013 
Henderson, J., An, J. \& Ma, H. 2018. The Archaeometry and Archaeology of Ancient Chinese Glass: A Review. Archaeometry, 60: 88-104. https://doi.org/10.1111/arcm.12368

Ibn Ḥayyān 2001. Crónica de los emires Alhakam I y Abdarraḥmān II entre los años 796 y 847 [Almuqtabis II-1]. Trans. by M. Alī Makkī \& F. Corriente. Zaragoza: La Aljaferia.

Krueger, I. 2014. Islamic Lead Glass and Mīnā. Journal of Glass Studies, 56: 61-84.

Malpica Cuello, A. ed. 2013. Mil años de Madinat Ilbira. Granada: Fundación El Legado Andalusí.

Mason, R.B. \& Tite, M.S., 1997. The Beginnings of Tin-Opacification of Pottery Glazes. Archaeometry, 39: 41-58. https://doi.org/10.1111/j.1475-4754.1997.tb00789.x

Mirti, P., Lepora, A. \& Saguì, L. 2000. Scientific Analysis of Seventh-Century Glass Fragments from the Crypta Balbi in Rome. Archaeometry, 42: 359-74. https://doi.org/10.1111/j.1475-4754.2000.tb00887.x

Mirti, P. Davit, P., Gulmini, M. \& Saguì, L. 2001. Glass Fragments from the Crypta Balbi in Rome: The Composition of Eighth-Century Fragments. Archaeometry, 43: 491502. https://doi.org/10.1111/1475-4754.00032

Molera, J., Pradell, T., Salvadó, N. \& Vendrell, M. 2009. Lead Frits in Islamic and Hispano Moresque Glazed Productions. In: A. Shortland, I. Freestone \& T. Rehren, eds. From Mine to Microscope: Advances in the Study of Ancient Technology. Oxford: Oxbow Books, pp. 1-10.

Molera J., Carvajal López J. C., Molina G. \& Pradell T. 2018. Glazes, Colourants and Decorations in Early Islamic Glazed Ceramics from the Vega of Granada (9th to $12^{\text {th }}$ Centuries CE). Journal of Archaeological Science: Reports, 21: 1141-51. https://doi.org/10.1016/j.jasrep.2017.05.017

Ocaña, M. 1963. Notas sobre la Córdoba de Ibn Hazm. al-Mulk, 3: 53-62.

Oliver, P. 1961. Islamic Relief Cut Glass: A Suggested Chronology, Journal of Glass Studies, 3: 9-29.

Paynter, S. 2001. The Development of Vitreous Materials in the Ancient Near East and Egypt (unpublished DPhil dissertation, University of Oxford).

Phelps, M., Freestone, I. C., Gorin-Rosen, Y. \& Gratuze, B. 2016. Natron Glass Production and Supply in the Late Antique and Early Medieval Near East: The Effect of the Byzantine-Islamic Transition. Journal of Archaeological Science, 75: 57-71. https://doi.org/10.1016/j.jas.2016.08.006 
Pollak, R. 2017. The Early Islamic Green Lead Glass from the Excavations at Caesarea Maritima, Israel. In: S. Wolf \& A. de Pury-Gysel, eds. Annales Fribourg/Romont 711 septembre 2015 du 20e Congrès de l'Association Internationale pour l'Histoire du Verre. Romont: Association Internationale pour l'Histoire du Verre, pp. 288-92.

Rontomé, E. 2006. El vidrio andalusí. In: E. Rontomé \& P. Pastor eds., Vidrio islámico en al-Andalus: exposición Real Fábrica de Cristales de La Granja, noviembre de 2006-abril de 2007. Cuenca: Fundación Centro Nacional del Vidrio: 37-50.

Salinas, E. 2013. Cerámica vidriada de época emiral en Córdoba. Arqueología y Territorio Medieval, 20: 61-96.

Salinas, E. \& Pradell, T. 2018. The Transition from Lead Transparent to Tin-Opacified Productions in the Western Islamic Lands: al-Andalus, c. 875-929 CE. Journal of Archaeological Science, 94: 1-11. https://doi.org/10.1016/j.jas.2018.03.010

Salinas, E. \& Pradell, T. 2020. The Introduction of the Glaze in al-Andalus: Technological Waves and Oriental Influences. Libyan Studies, 51: 187. https://doi.org/10.1017/lis.2020.8

Salinas, E., Pradell, T. \& Molera, J. 2018. Glaze Production at an early Islamic Workshop in al-Andalus. Archaeological and Anthropological Sciences, 11: 2201-13. https://doi.org/10.1007/s12520-018-0666-y

Schibille, N., De Juan, J., Casal, M.C. \& Guerrot, C. 2020. Ex novo Development of Lead Glassmaking in Early Umayyad Spain. Proceedings of the National Academy of Sciences of the United States of America, 117: 16243-49. https://doi.org/10.1073/pnas.2003440117

Shindo, Y. 2007. Lead Glass Found in the Räya and the Monastery of Wâdï al-Tur Sites. In: M. Kawatoki, et al. ed. Archaeological Survey of the Räyalal-Tür Area on the Sinai Peninsula, Egypt, 2005 and 2006. Islamic Archaeology and Culture, Vol. 1. Tokyo: Middle Eastern Culture Center in Japan, pp. 572-617.

Tite, M.S. 2008. Ceramic Production, Provenance and Use-A Review. Archaeometry, 50: 216-31. https://doi.org/10.1111/j.1475-4754.2008.00391.x

Tite, M.S., Freestone, I., Mason, R., Molera, J., Vendrell-Saz, M. \& Wood, N. 1998. Lead Glazes in Antiquity-Methods of Production and Reasons for Use. Archaeometry, 40: 241-60. https://doi.org/10.1111/j.1475-4754.1998.tb00836.x

Waksman, S.Y., Bouquillon, A., Cantin, N. \& Katona, I. 2008. Approche archéométrique des premières "Byzantine Glazed White Wares" et de productions glaçurées romaines et romaines tardives. Rei Cretariae Romanae Fautorum Acta, 40: 531-36. 
Walton, M.S. \& Tite, M.S. 2010. Production Technology of Roman Lead-Glazed Pottery and its Continuance into Late Antiquity. Archaeometry, 52: 733-59. https://doi.org/10.1111/j.1475-4754.2009.00506.x

Watson, O. 2014. Revisiting Samarra: The Rise of the Islamic Glazed Pottery. Beiträge zur islamischen Kunst und Archäologie, 4: 125-44.

Wood, N. 2001. The Influence of Glass Technology on Chinese Ceramics. Conference paper for The International Ceramics Fair and Seminar published by Haughton International [online] [accessed 4 February 2021]. Available at: $<\underline{\text { https://www.haughton.com/articles/2017/4/11/mcupv49cf16tki2bchxz7wfu7cpol6> }}$ Wood, N., Doherty, C. \& Rosser-Owen, M. 2009. A Technological Study of Iraqi Imitations of Chinese Changsha Wares and Chinese Sancai Wares Found at Samarra. Gu Taoci Kexue Jishu (Proceedings of the International Symposium on Ancient Ceramics 8). Beijing: ISAC, pp.154-80.

Wypyski, M. T. 2015. Chemical Analysis of Early Islamic Glass from Nishapur. Journal of Glass Studies, 57: 121-36.

\section{BIOGRAPHICAL NOTES}

Elena Salinas is a junior lecturer in Medieval History at University of Almería (UAL) and member of several R\&D projects, and ABDERA (UAL) and GCM (UPC) research groups. Her interests are focused on archaeology of al-Andalus, medieval ceramics and glaze technology.

Address: CEI·MAR, Universidad de Almería, Edificio Departamental de Humanidades y Ciencias de la Educación II (Edif. C,) Ctra. Sacramento s/n, La Cañada de San Urbano 04120 Almería, Spain. [email: esalinas@ual.es]. ORCiD: https://orcid.org/0000-00028306-3538

Jorge de Juan is a junior researcher at UNIARQ, the research archaeology centre of the School of Arts and Humanities (SAH) of the University of Lisbon (UL). He is specialist in the archaeology and materiality of the Iberian Peninsula and Northern West Africa in Modern and Medieval times. His work is currently mainly focused on archaeological glass types and compositions.

Address: UNIARQ, Faculdade de Letras da Universidade de Lisboa | School of Arts and Humanities, Alameda da Universidade 1600-214 Lisboa, Portugal. [email: jares@letras.ulisboa.pt]. ORCiD: https://orcid.org/0000-0001-9957-0342 
Juan M. Piñero has a degree in history (1999-2004) and a master's degree in archeology (2017) from the University of Granada, UGR. He is has been the project manager on different archaeological sites since 2004 and has participated in several projects in Spain, Italy (Universitat degli Studi di Salerno, UNISA), and the United Kingdom (Norfolk Archeology Unit, NAU). He is currently an Archaeologist at the Ministry of Culture and Historical Heritage of the Junta de Andalucía, Territorial Delegation in Huelva, Spain. Address: Junta de Andalucía, Spain, Barriada Andalucía 6, 3-C, Sanlúcar de Barrameda, 11540, Cádiz, Spain. [juanm.pinero@juntadeandalucia.es]

María Teresa Casal is a specialist in the Archaeology and History of al-Andalus. She has consolidated experience in research and in directing archaeological excavations, backed up by ten years of work as a researcher at the University of Cordoba (UCO) and the Municipal Management. She continued this research at the Institute of History of the CSIC (Madrid). She has carried out several research stays abroad and is the author of more than thirty specialised publications about Umayyad Islamic period of Cordoba (cementeries, urban development) as well as about the Shaqunda's eighth century suburb.

Address: Área de Arqueología, Facultad de Filosofía y Letras, Plaza del Cardenal Salazar, $\mathrm{n}^{\mathrm{o}}$ 3, 14071 Córdoba, Spain [casalmariateresa1@gmail.com]. ORCiD: https://orcid.org/0000-0001-8287-7567

Nadine Schibille is a senior research scientist at the French National Centre for Scientific Research (CNRS), Institut de Recherche sur les Archéomatériaux, Centre Ernest-Babelon (IRAMAT-CEB). She has a background in the history of art as well as in the technology and analysis of archaeological materials. She is currently leading an ERC-2014-CoG project entitled GlassRoutes (ID: 647315) that traces Mediterranean-wide developments in the production, trade and consumption of glass using analytical methods, such as laser ablation inductively coupled plasma mass spectrometry (LA-ICP-MS). Her interests include the materials and technologies of archaeological glass.

Address: IRAMAT-CEB, UMR5060, CNRS/Université d'Orléans, 3D, rue de la Férollerie, 45071 Orléans cedex 2, France. [nadine.schibille@,cnrs-orleans.fr] ORCiD: http://orcid.org/0000-0001-9242-0392

Trinitat Pradell is a full professor at the Physics Department of the Universitat Politècnica de Catalunya, BARCELONATECH, and is a member of the Materials Characterisation Group (GCM). She has been working on the analysis and characterisation of 
archaeological, historical, and artistic materials for 25 years. Her work has been mainly focused on glazed ceramics, stained glass, enamels, and decorative layers.

Address: Universitat Politècnica de Catalunya. Physics Department, Campus Diagonal Besòs, ES. Av. Eduard Maristany 14-16, edifici C, 08019 Barcelona, Spain. [Trinitat.Pradell@upc.edu]. ORCiD: http://orcid.org/0000-0002-8720-5492

\section{Du verre à la glaçure en al-Andalus : invention locale et transfert technologique}

Il a été proposé que la technologie de la glaçure plombifère ait précédé la production du verre en Europe occidentale et que cette technologie aurait ensuite été transférée au verre. Cet article présente de nouvelles données qui indiquent le contraire, c'est-à-dire une invention locale du verre et son transfert aux techniques de glaçure en al-Andalus (Espagne) au début de l'époque islamique. Des analyses de composition montrent que les glaçures plombifères de l'époque islamique de Cordoue sont liées à un type distinct de verre à haute teneur en plomb, ce qui met en évidence la relation étroite entre les deux technologies. Les vestiges archéologiques d'un atelier de potiers indiquent que le processus de production de la glaçure impliquait initialement la production de verre au plomb et n'était pas lié à la technologie romaine ou autres technologies contemporaines de la glaçure. Les données démontrent également que les potiers n'ont pas seulement utilisé les mêmes matériaux et techniques mais ont emprunté des motifs stylistiques et décoratifs à la verrerie. Translation by Madeleine Hummler

Mots-clés : technologie de la glaçure, glaçure céramique au plomb, technologie au haut Moyen Âge, atelier de potiers, creuset de verrerie

\section{Von Glas zu Glasur in al-Andalus: einheimische Erfindung und Technologietransfer}

Es wurde angenommen, dass die Technologie der Bleiglasur der Glasherstellung in Westeuropa vorausging und dass der Technologietransfer von Glasur zu Glas erfolgte. Die Ergebnisse der vorliegenden Untersuchungen zeigen jedoch, dass das Gegenteil der Fall war. Im frühislamischen al-Andalus in Spanien wurde zunächst Glas hergestellt und diese Technologie wurde dann auf Glasuren übertragen. Chemische Analysen zeigen, dass die Bleiglasuren der frühislamischen Zeit aus Córdoba eng mit einem bestimmten Typus von Bleiglas verwandt sind, was für einen Zusammenhang der beiden 
Technologien spricht. Das archäologische Fundmaterial aus einer Töpferwerkstatt deutet darauf hin, dass der Glasurprozess ursprünglich die Herstellung eines Bleiglases beinhaltete und nicht mit früheren römischen oder anderen zeitgenössischen Glasurtechnologien zusammenhängt. Die Daten zeigen auch, dass die Töpfer nicht nur die gleichen Techniken und Rohstoffe benutzten, sondern auch stilistische und dekorative Elemente der Glasherstellung entliehen. Translation by Madeleine Hummler

Stichworte: Glasurtechnologie, Bleiglasuren, frühmittelalterliche Technologie, Töpferwerkstatt, Schmelztiegel für Glasherstellung

\section{Figure captions}

Figure 1. (A) Location of the Andalusi sites studied. (B) Map of Madinat Qurtuba (Córdoba), during the Emirate period, with location of relevant archaeological sites.

Figure 2. Shaqunda lead glass assemblage.

Figure 3. Shaqunda glass workshop. Furnaces 1 and 2 show the characteristic round shape. The small size and shape of the furnaces are consistent with their use in the production of secondary glass. Scale on images: 1 metre.

Figure 4. Representative glazed ceramic debris from the Córdoba pottery workshop showing incised decoration in (A) honey-coloured and $(C)$ green glazes, applied threads in $(B)$ brown and $(D)$ green glazes. Overfired and cemented pieces $(E)$ and $(F)$.

Figure 5. (A) Glass crucible showing a (B) greenish transparent glassy layer on the walls and $(C)$ a darkened glassy layer covering the interior. The exterior of the crucible $(D)$ shows evident signs of having been in contact with a fire. Optical $(F)$ and SEM-BSE images $(G)$ and $(H)$ of the glassy layer.

Figure 6. Comparison of the chemical composition from the Shaqunda lead glass (red), the Shaqunda lead glass from the crucible (black), the Zumbacon glazes (blue) and the M. Auxiliadora glazes (green). The greater variability in the composition of the glazes is related to the interaction of the glazes with the ceramics during firing, but also because the glazes analysed are overfired debris.

Figure 7. Parallels between glass and glazed beakers: (A) glazed ceramic from Córdoba; (B) glass from Madinat Ilbira (redrawn from Malpica, 2013: 143, SOM01.IA.09.2033.1);

(C) glass from Madinat al-Zahra (redrawn from Rontomé, 2006: fig. 2). 

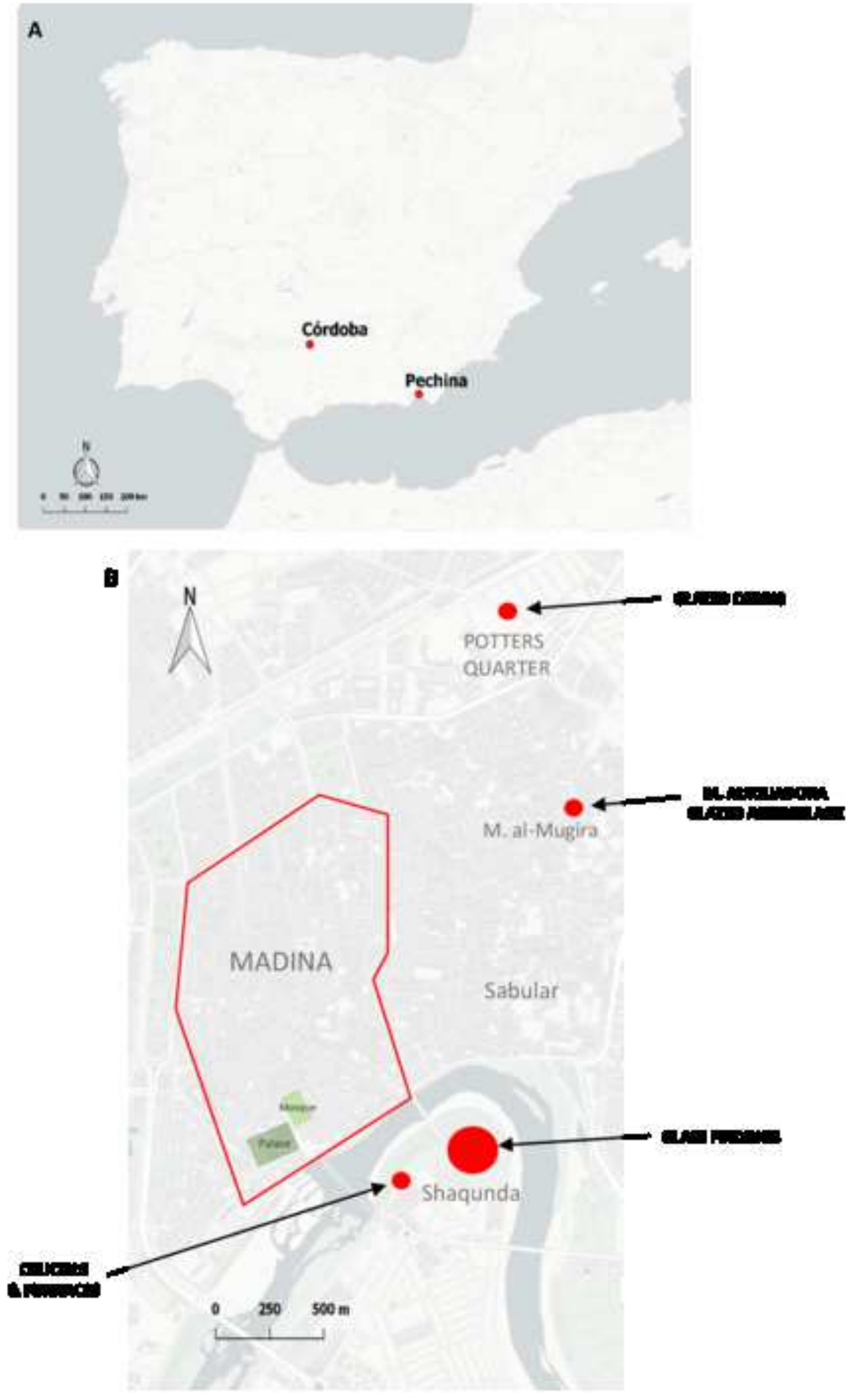

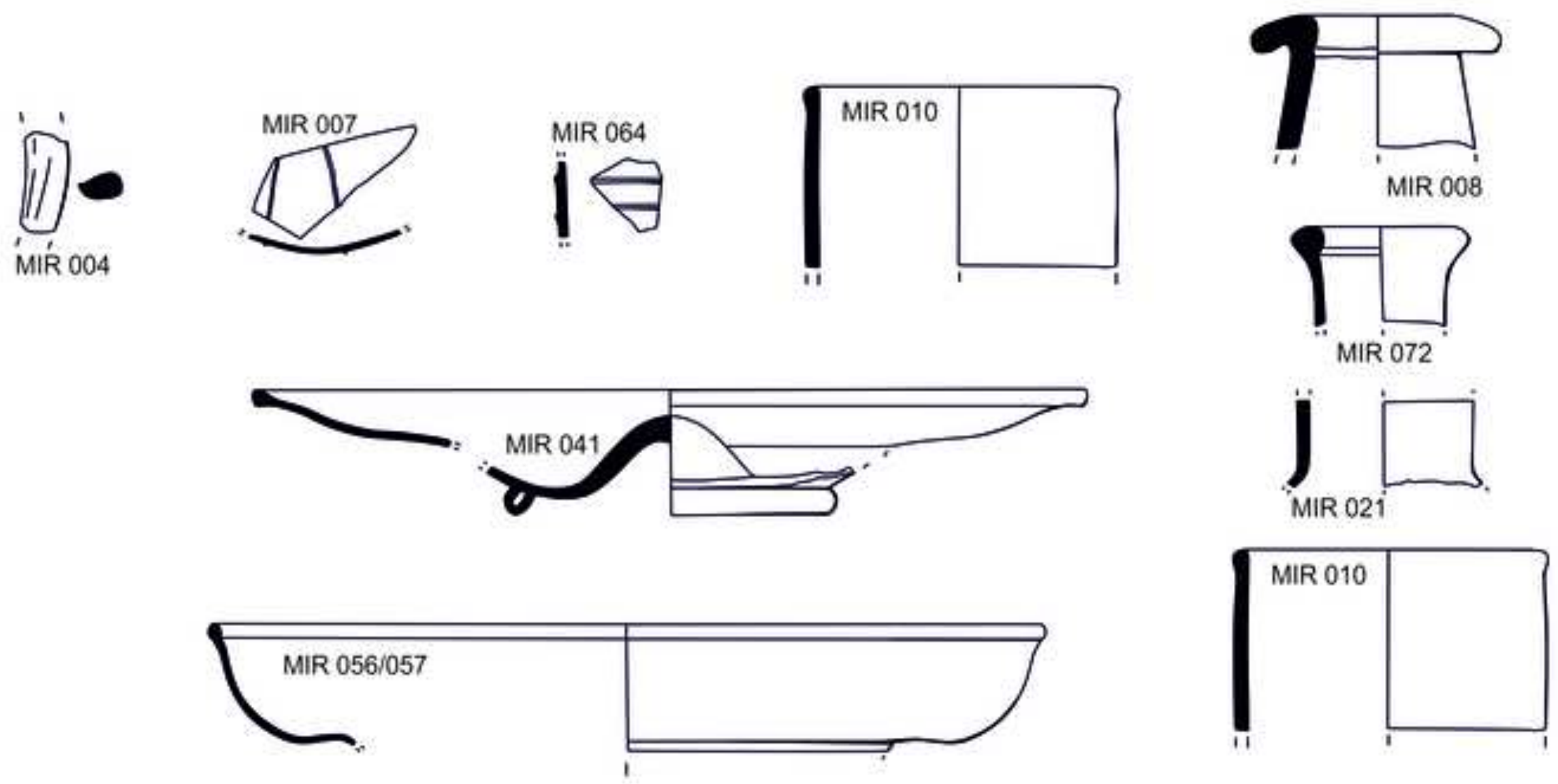

\section{MIR 006}
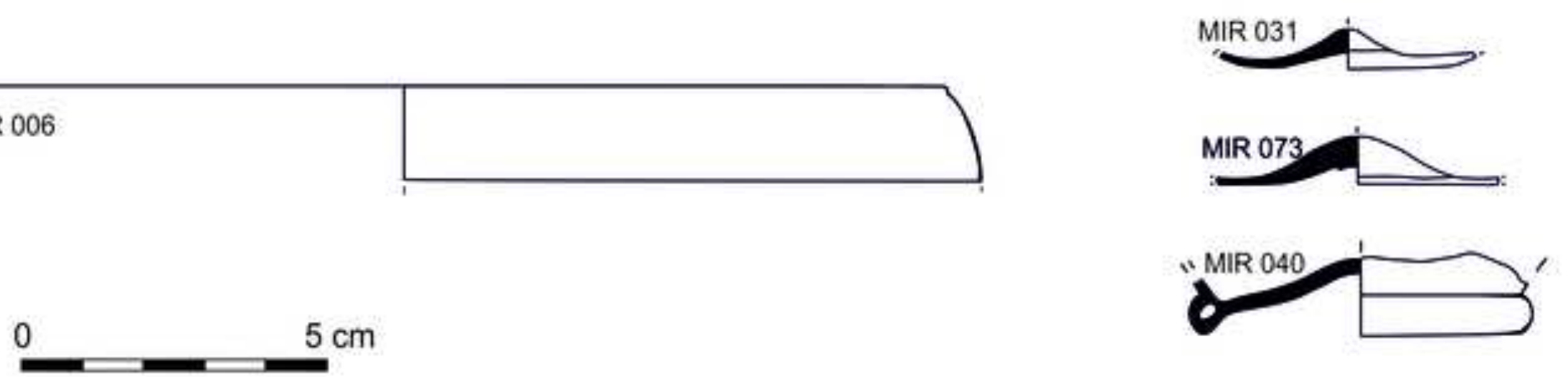


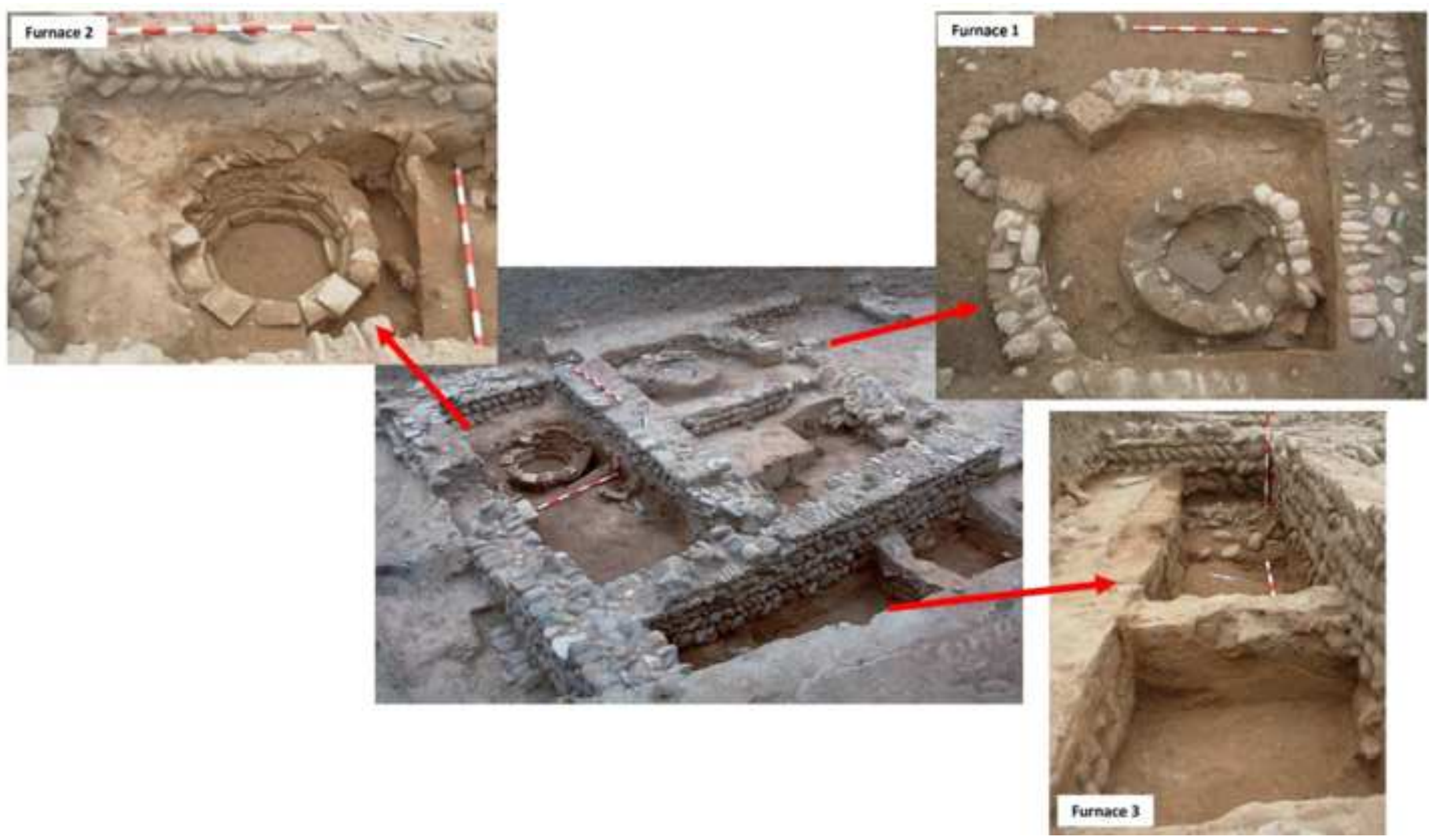



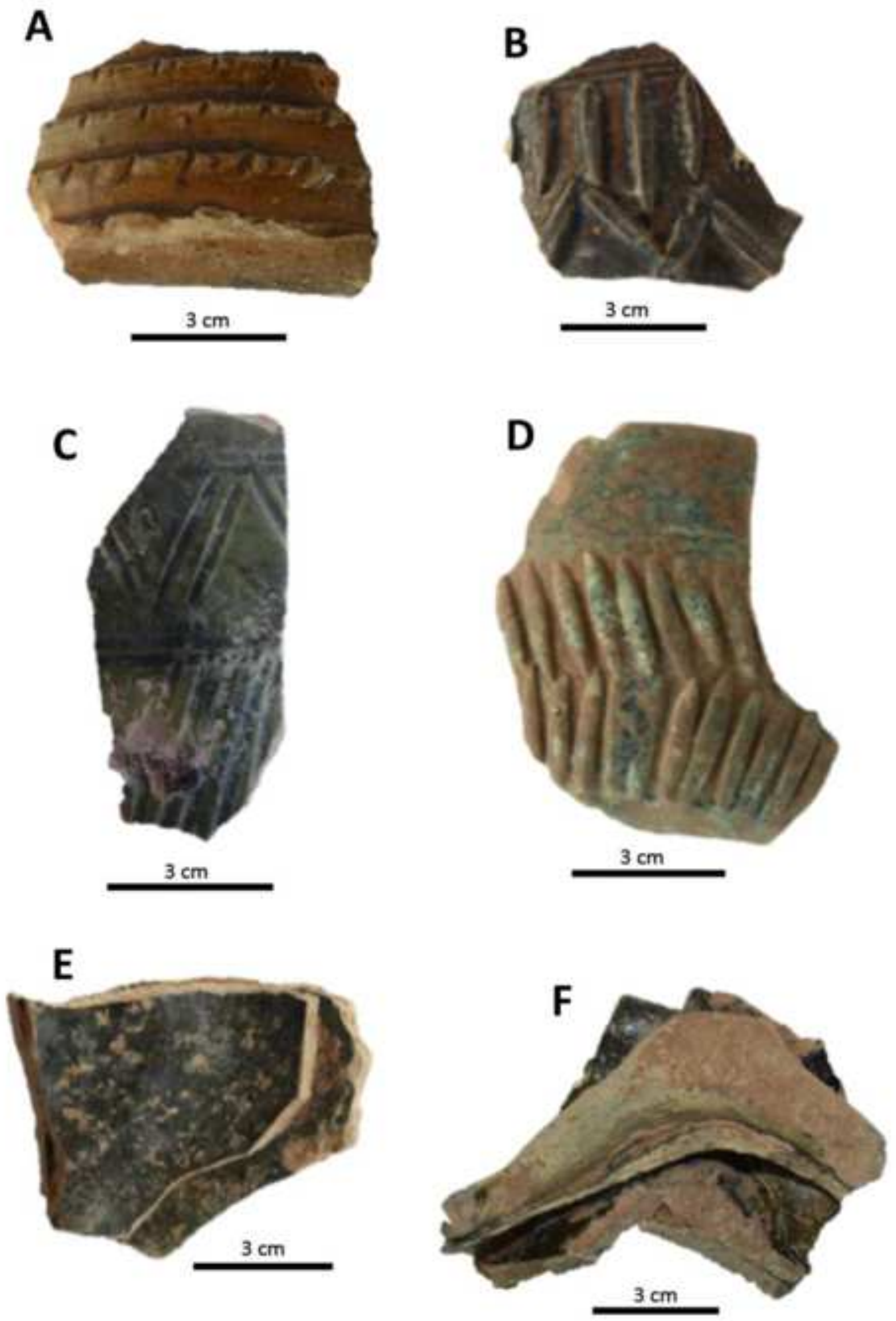

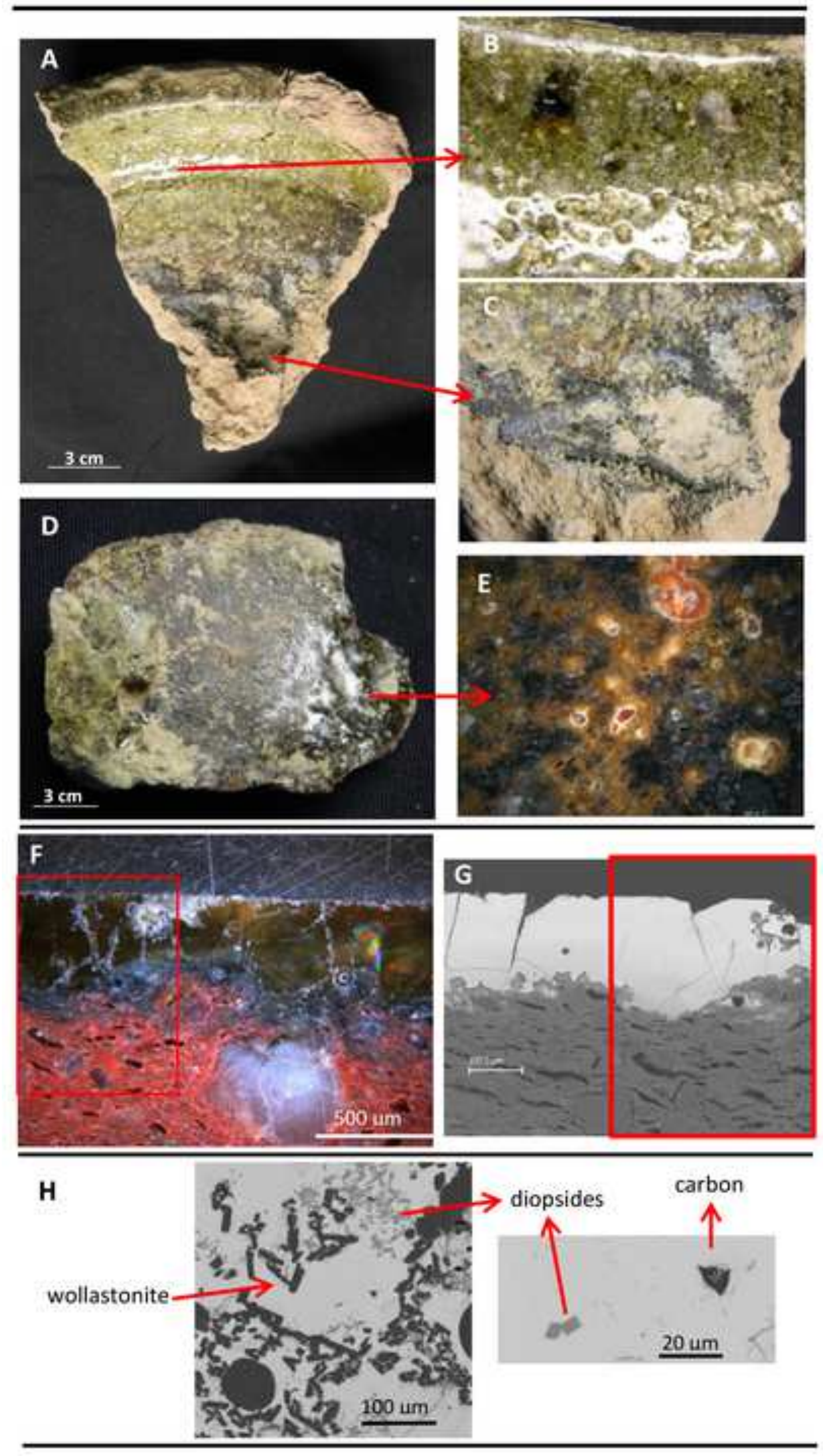

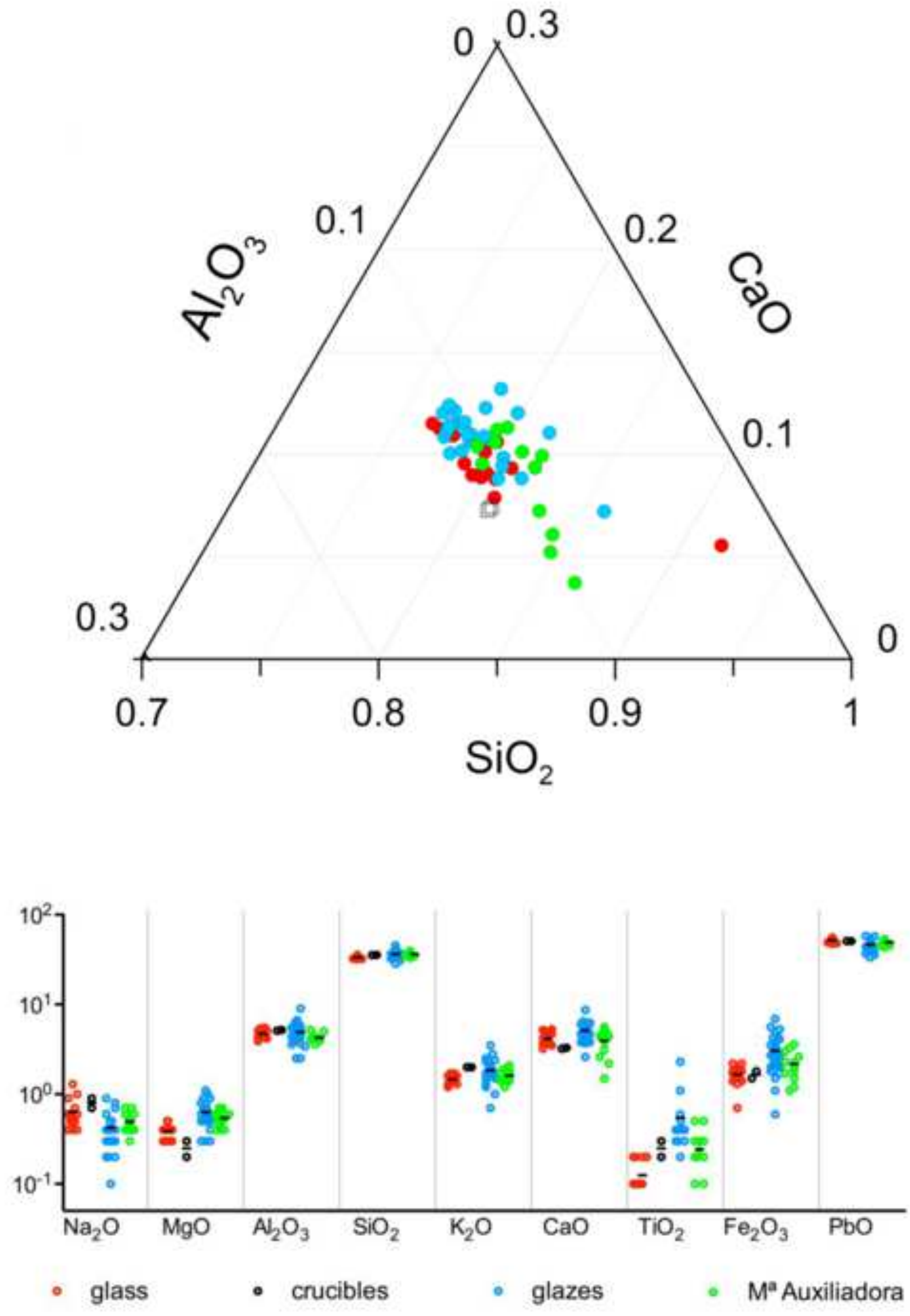
Click here to access/download;Colour figure (print: author charge may appy - please $\underline{\underline{ \pm}}$ contact the Editor for more details) [40 MB max file size];Fig 7.tif

A

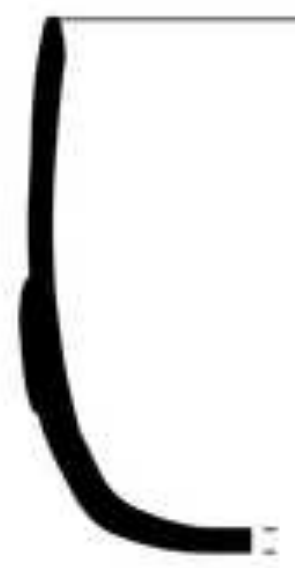

0

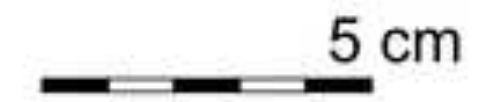

B

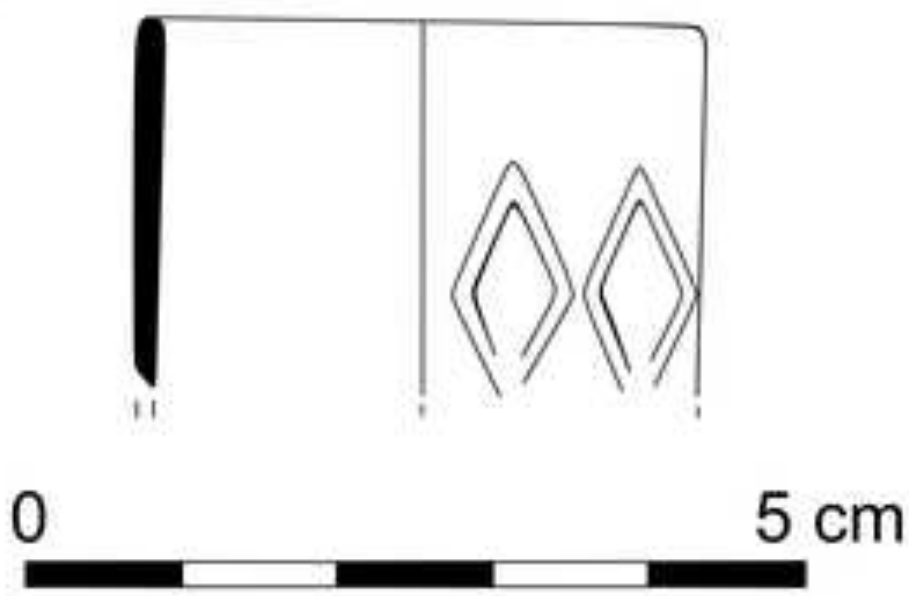

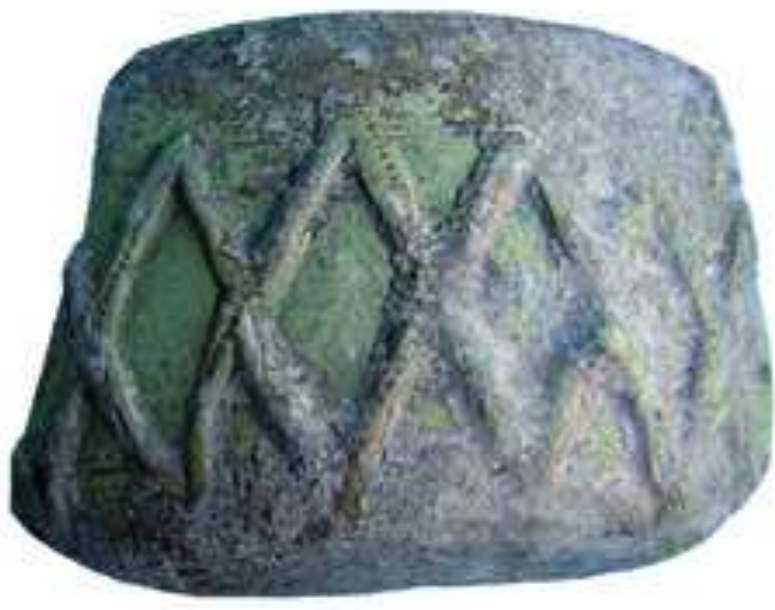

C

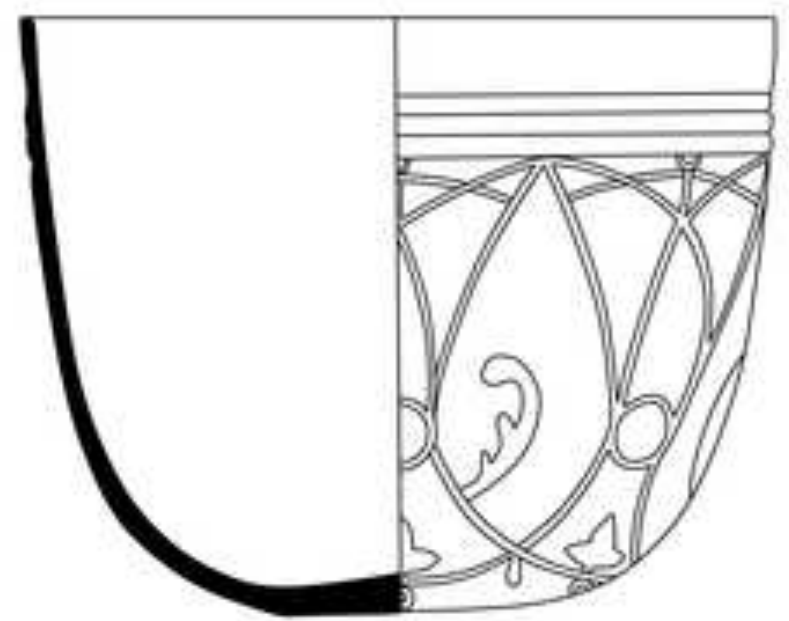

$5 \mathrm{~cm}$

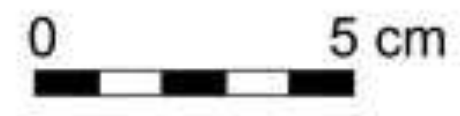




\section{From Glass to Glaze in al-Andalus: Local Invention and Technological Transfer Elena Salinas, Jorge de Juan, Juan M. Piñero, M. Teresa Casal, Nadine Schibille ANd Trinitat Pradell}

\section{SUPPLEMENTARY MATERIAL}

\section{Analytical Methods}

Polished cross-sections through the glazes of the sherds and of the crucibles were prepared. The polished sections were examined both in reflected light with an optical microscope and in a scanning electron microscope with energy-dispersive spectroscopy (SEM-EDS). A crossbeam workstation (Zeiss Neon 40) equipped with a SEM GEMINI (Shottky FE) column and EDS (INCAPentaFETx3 detector, 30 $\mathrm{mm}^{2}$, ATW2 window), operating at $20 \mathrm{KV}$ with 120 s measuring times was employed. The glaze and body microstructures were studied and recorded in backscatter mode (BSE), in which the different phases could be distinguished on the basis of their atomic number contrast.

For the chemical compositions of the glazes, areas of weathered glaze and areas near to the interface between the glaze and the fabric were avoided as far as possible. As a result, the glaze totals varied between 97 and 99 per cent, mainly because of the variable state of preservation of the glazes. The analyses were therefore averaged without normalization. An EDS elemental microanalysis system calibrated with oxide and mineral standards and a high lead glass (K229) was used to determine the composition of the glazes (Geller Microanalytical Laboratory, MA, USA). Typical detection limits are 0.1 per cent for $\mathrm{Na}, \mathrm{Mg}, \mathrm{Al}, \mathrm{P}, \mathrm{K}, \mathrm{Ca}, \mathrm{Ti}, \mathrm{Mn}$ and $\mathrm{Fe}, 0.2 \%$ for $\mathrm{Si}$ and $\mathrm{Cu}$ and 0.4 per cent for $\mathrm{Pb}$.

The glass samples were mounted in epoxy resin and polished to remove possible corrosion layers. They were analysed by LA-ICP-MS (Schibille et al, 2020). The instrumental setup was a mass spectrometer Thermofisher Element XR and the laser ablation system Resonetic UV laser microprobe (193 nm Excimer laser). The operating conditions were set at $5 \mathrm{~mJ}$ with a frequency of $10 \mathrm{~Hz}$ and a spot size diameter of $100 \mu \mathrm{m}$ that was reduced down to $40 \mu \mathrm{m}$ for glasses with high lead concentrations. A pre-ablation time of $15 \mathrm{~s}$ was followed by a $30 \mathrm{~s}$ analysis time measuring fifty-eight elements (for details see Schibille et al, 2020). 
Table S1. Average composition (avg) and standard deviation (stdev) of the Córdoba high-lead glass determined by LA-ICP-MS (Schibille et al., 2020), the compositional data of two Córdoba glass crucible determined by SEM-EDS (wt\% normalized to 100 wt\%), and chemical composition of the Córdoba glazes determined by SEM-EDS (wt\% normalized to 100 wt\%).

\begin{tabular}{|c|c|c|c|c|c|c|c|c|c|c|c|c|c|c|c|c|}
\hline Group & Sample & Colour & Object type & $\mathrm{Na}_{2} \mathrm{O}$ & MgO & $\mathrm{Al}_{2} \mathrm{O}_{3}$ & $\mathrm{SiO}_{2}$ & $\mathrm{P}_{2} \mathrm{O}_{5}$ & $\mathbf{C l}$ & $\mathrm{K}_{2} \mathrm{O}$ & $\mathrm{CaO}$ & $\mathrm{TiO}_{2}$ & MnO & $\mathrm{Fe}_{2} \mathrm{O}_{3}$ & $\mathrm{CuO}$ & PbO \\
\hline \multirow{2}{*}{ Saqunda glass $(\mathrm{n}=15)$} & avg & & & 0.6 & 0.4 & 4.7 & 33.6 & 0.2 & 0.1 & 1.4 & 4.2 & 0.1 & 0.1 & 1.7 & & 52.2 \\
\hline & stdev & & & $(0.2)$ & $(0.1)$ & $(0.5)$ & $(1.2)$ & $(0.0)$ & $(0.0)$ & $(0.1)$ & $(0.7)$ & $(0.0)$ & $(0.0)$ & $(0.3)$ & & $(2.7)$ \\
\hline \multirow{2}{*}{ Glass Crucible } & & & & 0.7 & 0.2 & 5.1 & 35.6 & - & 0.1 & 2.0 & 3.3 & 0.3 & - & 1.8 & 0.1 & 50.9 \\
\hline & & & & 0.9 & 0.3 & 5.2 & 35.5 & - & - & 2.0 & 3.2 & 0.2 & - & 1.5 & 0.2 & 50.9 \\
\hline \multirow{21}{*}{ Zumbacón Lead glaze } & $\mathrm{Z3}$ & Honey & Beaker & 0.3 & 0.5 & 3.4 & 33.6 & - & - & 1.6 & 5.1 & - & 0.2 & 5.6 & 0.1 & 49.6 \\
\hline & \multirow{2}{*}{ Z11 } & Honey & \multirow{2}{*}{ Pitcher? } & 0.3 & 0.7 & 5.8 & 39.1 & - & - & 1.6 & 5.6 & - & 0.2 & 3.2 & 0.4 & 43.0 \\
\hline & & Honey (outer) & & 0.3 & 0.7 & 6.3 & 41.3 & - & - & 2.1 & 5.8 & 1.1 & - & 2.7 & - & 39.7 \\
\hline & $\mathrm{Z} 12$ & Green & Beaker & 0.2 & 0.5 & 2.5 & 28.6 & - & - & 1.2 & 3.9 & - & - & 1.1 & 4.7 & 57.3 \\
\hline & Z14 & Honey & Beaker? & 0.6 & 0.9 & 5.0 & 40.2 & - & - & 2.0 & 4.7 & 0.3 & 0.3 & 6.9 & 0.4 & 38.8 \\
\hline & \multirow{2}{*}{ Z15 } & Green & \multirow{2}{*}{ Beaker } & 0.7 & 0.9 & 3.7 & 35.6 & - & - & 1.9 & 6.0 & - & - & 2.1 & 2.9 & 46.2 \\
\hline & & Green & & 0.9 & 0.8 & 4.1 & 34.0 & - & - & 1.9 & 5.3 & - & - & 2.2 & 2.9 & 47.9 \\
\hline & \multirow{2}{*}{$\mathrm{Z} 30$} & Honey & \multirow{2}{*}{ Pitcher? } & 0.4 & 0.7 & 5.7 & 39.2 & - & - & 1.9 & 5.8 & - & - & 4.3 & 0.4 & 41.9 \\
\hline & & Honey & & 0.5 & 0.6 & 4.8 & 35.2 & - & - & 1.9 & 4.8 & - & - & 4.1 & 0.2 & 47.9 \\
\hline & \multirow{2}{*}{$\mathrm{Z} 31$} & Honey (inner) & \multirow{2}{*}{ Dish } & 0.5 & 0.7 & 5.5 & 35.6 & - & - & 1.8 & 4.6 & 0.4 & - & 3.5 & - & 47.6 \\
\hline & & Honey (inner) & & 0.4 & 0.5 & 5.3 & 36.3 & - & - & 1.7 & 4.7 & 0.4 & - & 2.7 & - & 48.0 \\
\hline & \multirow{2}{*}{$\mathrm{Z} 32$} & Honey (inner) & \multirow{2}{*}{ Dish } & 0.4 & 0.7 & 5.2 & 37.6 & - & - & 2.4 & 5.9 & - & - & 2.0 & - & 45.0 \\
\hline & & Honey (inner) & & 0.5 & 0.5 & 4.3 & 33.4 & - & - & 1.6 & 4.6 & 0.2 & - & 1.7 & 0.7 & 52.2 \\
\hline & \multirow{2}{*}{$\mathrm{Z} 40$} & Green (outer) & \multirow{2}{*}{ Pitcher } & 0.1 & 0.5 & 3.6 & 33.5 & - & - & 1.0 & 3.8 & - & - & 2.0 & 2.3 & 53.2 \\
\hline & & Honey (inner) & & 0.2 & 0.5 & 2.5 & 30.7 & - & - & 0.7 & 2.6 & - & 0.2 & 4.4 & - & 58.2 \\
\hline & Z49 & Honey (inner) & Beaker & 0.5 & 0.7 & 5.5 & 38.8 & - & - & 2.3 & 6.3 & - & - & 4.9 & 0.3 & 40.8 \\
\hline & $\mathrm{Z} 52$ & Honey & Unknown & 0.3 & 0.8 & 5.4 & 39.6 & - & - & 1.5 & 5.5 & 0.4 & - & 2.7 & - & 44.1 \\
\hline & $\mathrm{Z} 54$ & Transparent & Unknown & 0.8 & 0.4 & 4.1 & 35.4 & - & - & 1.5 & 3.8 & 2.3 & - & 0.6 & - & 51.4 \\
\hline & $\mathrm{Z} 60$ & Honey & Pitcher? & 0.4 & 0.3 & 4.4 & 33.9 & - & - & 1.3 & 3.7 & 0.4 & - & 5.3 & - & 50.2 \\
\hline & Z66 & Green & Beaker & 0.2 & 0.6 & 5.0 & 36.5 & - & - & 2.0 & 5.1 & 0.4 & 0.3 & 2.9 & 3.5 & 43.6 \\
\hline & Z68 & Honey (inner) & Dish & 0.5 & 0.3 & 3.9 & 32.2 & - & - & 1.7 & 3.9 & 0.3 & - & 1.5 & 0.6 & 55.1 \\
\hline
\end{tabular}




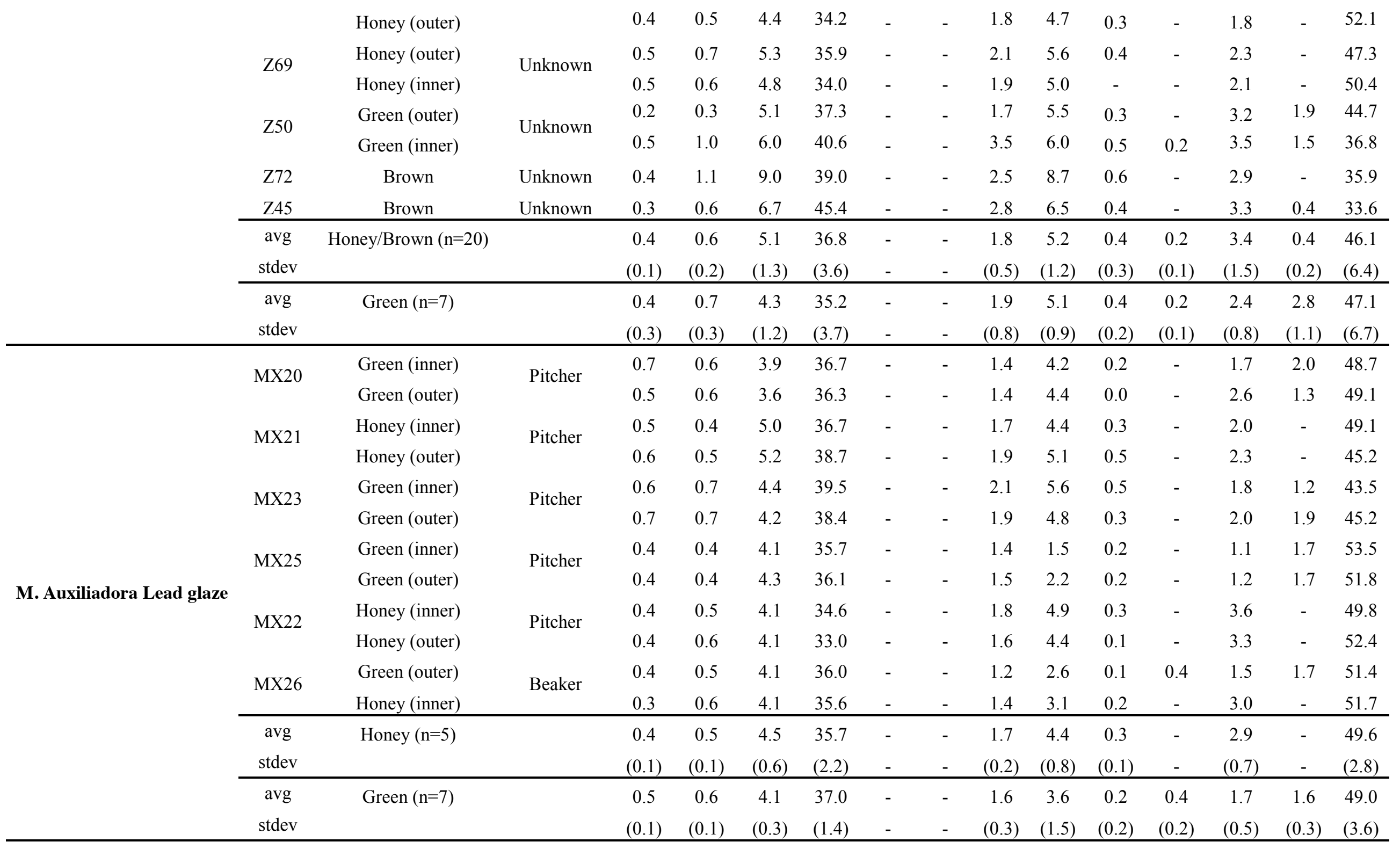

